Año L. urtea

$125-2018$

Urtarrila-ekaina Enero-junio

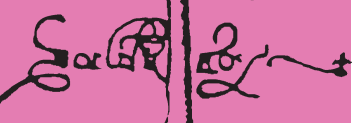

(ans

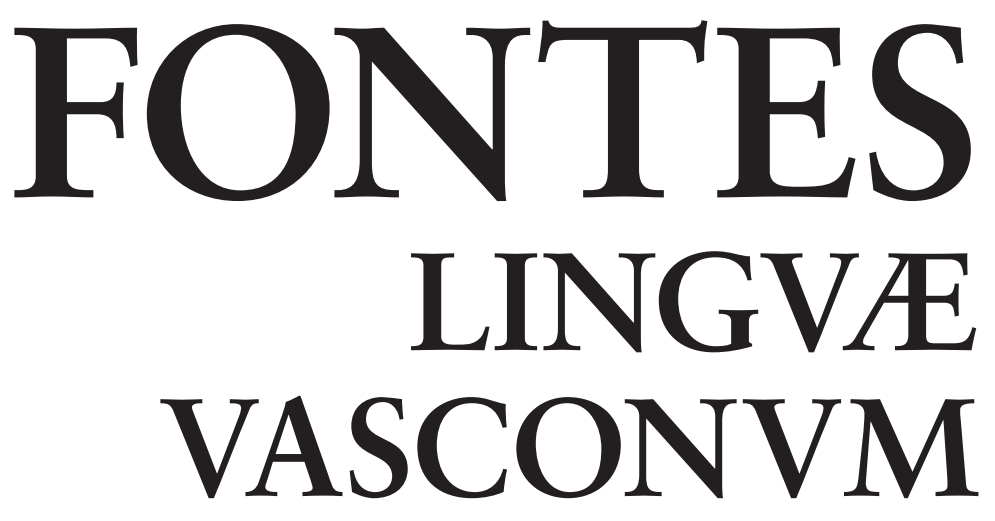

STVDIA ET DOCVMENTA

SEPARATA

\section{Oiartzungo \\ azentuera zaharra}

José Ignacio Hualde

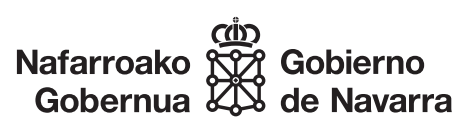

0000 


\title{
Oiartzungo azentuera zaharra
}

\author{
La acentuación antigua del habla de Oiartzun
}

The old accentual system of Oiartzun Basque

José Ignacio HUALDE

University of Illinois at Urbana-Champaign

jihualde@illinois.edu

Eskerrak eman nahi dizkiet Aritz Irurtzuni grabaketaren kopia digital bat niri helarazteagatik eta Elixabete Pérez Gazteluri grabaketa erabiltzeko baimena emateagatik. Mila esker Oihana Lujanbiori eta FLVko ebaluatzaile anonimoei artikuluari egindako iruzkinengatik.

Jasotze data: 08/01/2018. Behin-behineko onartze data: 19/02/2018. Behin betiko onartze data: 21/02/2018. 


\section{LABURPENA}

Mitxelenak argitaratu gabe utzitako langaien artean grabaketa bat dugu. Grabaketaren helburua azentu bereizkuntzak aztertzea zen. Azterketa hori egiteko, Mitxelenak Oiartzungo hiztun bat elkarrizketatu zuen. Hemen grabaketan agertzen diren azentu patroiak miatzen ditugu eta Mitxelenak egindako sailkapenarekin elkartzen ditugu. Ondorio nagusia da orduko Oiartzungo sistemak antza handia zuela oraindik ere Goizuetan erabiltzen den azentuerarekin.

Gako hitzak: euskal azentua; Oiartzungo hizkera; Mitxelenaren langaiak.

\section{RESUMEN}

Entre los materiales que Mitxelena nos dejó sin publicar hay una grabación preparada para estudiar los contrastes acentuales. Mitxelena entrevistó a un hablante de Oiartzun para este propósito. En este trabajo analizamos los patrones acentuales que aparecen en la grabación y los comparamos con la clasificación hecha por Mitxelena. El principal resultado es que el sistema acentual que se empleaba en Oiartzun en esa época tenía gran semejanza con el que todavía encontramos en Goizueta.

Palabras clave: acento vasco; habla de Oiartzun; materiales de Mitxelena.

\section{ABSTRACT}

Among the research materials that Mitxelena left unpublished we find a recording that he prepared in order to study accentual contrasts in Basque. For this purpose, Mitxelena interviewed a speaker from Oiartzun. In this paper, we analyze the accentual patterns that are found in the recording and compare them with Mitxelena's classification. The main result is that the accentual system that was employed in Oiartzun at the time was rather similar to that still found in Goizueta.

Keywords: Basque accent; Basque dialect of Oiartzun; Mitxelena's materials.

114 Fontes Linguae Vasconum (FLV), 125, enero-junio, 2018, 113-132

ISSN: 0046-435X ISSN-e: 2530-5832 
1. Sarrera. 2. AZENTU Patroiak. 3. Singularraren ETA Pluralaren aZENTUera 4. MitXELENAREN SAILKAPEN BITARRA ETA CORPUSEKO HITZEN BANAKETA PROSODIKOA: KONPARAKETA. 4.1. Klase II-ko hitzak. 4.2. Klase III-ko hitzak. 5. LABURBILDUZ. 6. IRUDIAK. 7. ERREFERENTZIAK.

\section{SARRERA}

Jakina denez, Koldo Mitxelenak arreta berezia jarri zuen euskal azentuaren ikerketan Fonética Histórica Vasca-n eta beste lan askotan; batez ere hizkuntzaren bilakaera historikoa berreraikitzeko izan dezakeen garrantziagatik. Hain zuzen, heriotza iritsi zitzaionean, gai honetaz zenbait langai utzi zituen argitaratu gabe, María Teresa Echeniqueri esker ezagutzen ditugunak (Echenique, 1988).

Echeniquek argitara emandako artikuluan, beste gauza askoren artean, hitz zerrenda luze bat aurkitzen dugu, Mitxelenak azentu bereizkuntzak aztertzeko prestatu zuena. Zerrenda horretan hitzak bi zutabetan daude antolatuta, «normales» eta «anormales» deituren pean. Zerrendaren hasieran Mitxelenak azaltzen duenez, hitz normaletan singularra eta plurala bereizten dira doinuaren bidez eta ez-normaletan ez. Gehitzen du Mitxelenak hitzen banaketa bitarra Errenteriko euskararen hiztun bezala zeukan ezagutzaren araberakoa dela.

Mitxelena hitz zerrenda horretaz baliatu zen grabaketa bat egiteko; hau da, nolabait bere hipotesiak aztertzeko. Aritz Irurtzunen lanaren bidez grabaketa horren berri dugu, euskal azentuari buruzko lan bat osatzeko erabili baitzuen (Irurtzun, 2006). Ez dakit grabaketa noizkoa den. Hemen Mitxelenak, Echeniquek eta Irurtzunek egindako lanari jarraipena eman nahiko nioke.

Erabili dudan grabaketan elkarrizkatuta Pedro Berrondo (1919-2002) euskal idazle eta itzultzaile oiartzuarra dugu. Daukadan grabaketa digilizatua in medias res edo hasten da, elkarriztatuaren izena edo beste xehetasunik eman gabe, baina momentu batean 
Mitxelenak bere izena euskaraz esateko eskatuta, hiztunak bi modutan ematen digu, lehenik Berrondo'tar Pedro, garaiko usadioan, eta gero ohiko hurrenkeran. Hiztuna nor zen eta bere bizitzaz ezer jakin gabe ere (ikus Wikipedia euskaraz), garbi dago grabaketaren edozein entzulerentzat kultura handiko gizona zela eta erreztasun osoz irakurtzen zuela euskaraz ${ }^{1}$. Berrondok euskararen gainean zeukan ezagutza ez zen inolaz ere mugatzen umetan ikasitako hizkerara. Hala ere, argi dago Oiartzungo euskararen lekuko bikaina aukeratu zuela Mitxelenak. Grabaketan Berrondok gogoratzen dio Mitxelenari baserrian jaiotakoa zela, baserri munduko hiztegia ondo ezagutzen zuela adierazteko. Izan bedi artikulu xume hau Koldo Mitxelenaren eta Pedro Berrondoren omenez.

Artikulua honelaxe dago antolatuta: 2. atalean, datuen analisi akustikoa eginda agertzen diren azentu patroiak deskribatzen dira. Aipatu dudanez, Mitxelenak esaten digu «hitz normalekin» singularra eta plurala bereizten direla azentuaren bidez. Hala ere, bere hitz zerrenda egin zuenean bereizkuntza horren izaera ez zuen aztergai. 3. atalean singularren eta pluralen azentueraz esan dezakeguna adierazten dut. 4. atalean nire azterketa eta hitzen sailkapen prosodikoa Mitxelenak aldez aurretik egindakoarekin konparatzen dut, ikusteko zein neurritan hitzen banaketak antzekoak diren Mitxelenak prestatutako langaian eta Berrondoren ahoskeran. 4.1. eta 4.2. azpiataletan azentu patroi markatuen banaketa lexikala eta horri buruz egin ditzakegun orokorpenak kontsideratzen ditut. Azkenik, 5. atalean emaitzak laburbiltzen ditut.

\section{AZENTU PATROIAK}

Erabili dudan grabaketan ondo entzuten diren hitzak banan banan segmentatu ditut eta azentuaren ezaugarri akustikoak (tonua, intentsitatea eta iraupena) aztertu Praat programaren bidez (Boersma \& Weenink, 2017).

Mitxelenak prestatutako hitz zerrendan hitzak bi zutabetan badaude ere, doinuera kontuan hartuz gero hiru hitz mota behintzat aurkitzen ditugu grabaketan. Esan bezala, antolakuntza bi azentu klasetan Mitxelenaren Errenteriko hizkerarena da, hiztun bezala zeuzkan intuizioen arabera, eta Berrondok, aldiz, Oiartzungo azentuera erabiltzen du. Argi dago Mitxelenaren eta Berrondoren azentuerak desberdinak zirela. Batzuetan Mitxelenak Berrondok esandako hitz bat errepikatzen du edo galdetzen dio ea hitza Oiartzunen erabiltzen den. Kasu horietan, askotan bi hiztunek modu desberdinetan azentuatzen dituzte hitzak. Hala ere, ikusiko dugunez, gehienetan Mitxelenak «ez-normal» bezala sailkatu zituen hitzak bereziak dira Berrondoren hizkeran ere, nahiz eta bereizkuntza prosodikoa beste modu batean egin.

Akustikoki analizatu ditudan datuetan, hitz gehienetan badago tonu gailur bat bigarren silaban eta beste bat bukaeran, adib. afáiyá' 'afaria', aldékuá, la(r)únbatá

1 Adibidez, hitz batzuen esanahia argitzeko parentesco colateral eta enclítico bezalako hitz teknikoak erabiltzen dituzte Mitxelenak eta Berrondok.

2 Adibideak Mitxelenak erabiltzen duen grafian ematen ditut, nire tonu markak gehituz. 
(ikus 1-3. irudiak, artikuluaren bukaeran). Beste hitz batzuetan lehen goiko tonua lehendabiziko silaban kokatzen da, adib. bázkayá 'bazkaria', kálekuá, láunaká (ikus 4-6. irudiak). Hitz klase hau ttikiagoa da. Azkenik, hirugarren hitz mota batean, badago gorakada bakar bat, bukaeran, adib. gosaiyá 'gosaria', aldikúa, labañá (ikus 7-9. irudiak).

Kasu guztietan, badirudi ondoriozta dezakegula bukaeran kokatzen den goiko tonua esaldi-mailakoa dela eta desagertzen dela beste testuinguruetan, nahiz eta horretarako ebidentzia gutti aurkitzen den grabaketan, adib: Xoxokó baina Xoxokok esán du. Esan dezakegu erroan goiko tonurik ez daukaten hitzek beheko tonua dutela. Bukaerako tonu gailurra alde batera utziz, beraz, baditugu hiru hitz mota, (1)ean erakusten den bezala. Goiko edo goranzko tonua azentu akutuaren bidez adierazten dut eta behe(ranz) ko tonua azentu grabeaz:

(1) Hitz klase prosodikoak

Klase I: Goranzko tonua bigarren silaban; adib. /afáiya/ afáiyá

Klase II: Goranzko tonua lehen silaban; adib. /bázkaya/ bázkayá

Klase III: Beheranzko tonua; adib. /gosàiya/ gosàiyá

Hau, noski, funtsean Goizuetan gaur egun aurkitzen dugun sistema da (Hualde \& Lujanbio, 2008; Hualde, 2008; Hualde, Lujanbio \& Torreira, 2008) eta bat dator baita Jacobsenen (1972, 84-85. or.) Oiartzungo azentueraren deskribapen labur baina zehatzarekin ere. Goizuetan argi dago azentu lexikala beti erroaren lehen edo bigarren silaban kokatzen dela eta hitz solteen edo galdegaiaren bukaeran agertzen den tonu gailurra esaldi-mailako gertakari bat dela (adib. Goiz. zakùrraná 'pl' baina zakùrran itxéa). Nahiz eta, esan bezala, gure grabaketan ebidentzia asko ez egon hau baieztatzeko, ontzat emango dut horrela dela eta errepresentazio fonologikoetan bakarrik erroko tonua, goranzkoa zein beheranzkoa, markatuko dut.

Goizuetan, dena den, lau hitz klase prosodiko ditugu, ez hiru, beheranzko tonua duten hitzek tonu hori lehen edo bigarren silaban izan baitezakete. Goizuetan bokalaren iraupenak modu argi batean adierazten digu beti silaba azentuduna zein den eta, beraz, tonua zein silabari dagokion. Aztertzen ari garen datuetan, aldiz, iraupen diferentziak ttikiagoak dira eta ez dago beti hain garbi zein den silaba azentuduna erroak beheranzko tonua daramanean. Adibide batzuetan erabaki daiteke azentua non dagoen iraupenaren eta intentsitatearen bidez, adib. platè:rá /platèra/, serò:rá /seròra/ vs prè:miyá /prèmiya/ (bokal luzeagoak bi punturekin adierazten ditut, ikus 10-11 irudiak) baina beste askotan ez da erreza. Hau jakingo genuke argiago singularplural pareak izango bagenitu, baina ia ez dago horrelakorik grabaketan (ikus hurrengo atala).

Nire susmo edo hipotesia da, Goizuetan bezala, badirela lau hitz mota azentuaren arabera fonologikoki, eta ez hiru bakarrik, baina askotan beheranzko azentuaren kokagunea lehen edo bigarren silaba den erabakitzea zaila denez, hemen egiten dugun sailkapenean talde bakar bat osatuko dugu beheranzko tonua daukaten hitzekin, (1)an erakusten den bezala. 
3. Goranzko vs beheranzko azentuen arteko kontrastea pare kuasi-minimo batekin erakusten dugu 12-13 irudietan: belárrián 'belarrean' vs belàrriyá 'belarria'.

\title{
3. SINGULARRAREN ETA PLURALAREN AZENTUERA
}

Mitxelenak esaten digu bere hitz «normaletan» singularra eta plurala bereizten direla prosodiaren bidez, baina azentua aztertzeko prestatu zuen zerrendan ez zuen espresuki singular-plural bikoterik jarri. Dena den, pare minimo bat aurkitzen dugu hiru aldiz, gizónak 'erg sg' vs gizònak 'abs-erg pl', lehen kasualitatez (hiztunak hitza pluralean irakurri zuen gaztelaniazko itzulpena ikusi baino lehen) eta gero Mitxelenak apropos lortu nahi zuen esaldi-mailako kontraste batetan. Hitz honekin singularrean goranzko tonu bat dugu bigarren silaban (ikus 15. irudia) eta pluralean, aldiz, beheranzko tonua (ikus 14. irudia), Jacobsenek (1972) ere deskribatu zuen bezala. Honetan ere Oiartzungo sistemak antza du Goizuetakoarekin (Irurtzun, 2006).

(2) Tonu aldaketa pluralean

Erg sg: gizónak é (= ere) /gizónak/

Abs-erg pl: gizònák/gizònak/

\author{
gizónak ekárri ttu 'el hombre los ha traído' (= 14. irudia) \\ gizònak ekárri ttu '(alguien) ha traído a los hombres' (= 15. irudia)
}

Jacobsenek (1972, 85. or.) egin zuen analisian Oiartzungo euskaraz lehendabiziko silaban goranzko tonua zuten hitzek beheranzko tonua hartzen zuten silaba horretan pluralean, adib. erg sg sémiak vs abs-erg pl sèmiak. Goizuetan ere horrela da (Hualde \& Lujanbio, 2008; Hualde et al., 2008). Hala ere, gure grabaketan sémiá (= sémia $)$ singularra aurkitzen badugu ere, mota honetako hitzen pluralik ez dago absolutibo edo ergatiboan. Komitatiboan adibide bat dugu (hau ere kasualitatez jasota): ánkakin (= ánkakin) 'oinarekin' vs ànkakin (= ànkakin) 'oinekin'. Badirudi, beraz, singularraren eta pluralaren arteko bereizkuntza prosodikoa Goizuetan bezala egiten zela Oiartzunen: azentuaren melodia aldatuz baina kokagunea aldatu gabe.

\section{MITXELENAREN SAILKAPEN BITARRA ETA CORPUSEKO HITZEN BANAKETA PROSODIKOA: KONPARAKETA}

Esan bezala, Mitxelenak bi zutabetan antolatu zituen hitzak azentuaren arabera: normalak («normales») eta bereziak («anormales»). 2. atalean, aldiz, hiru (edo lau) klase prosodiko desberdin bereizi ditugu. Egin dezakegun galdera bat da nola elkartzen den Mitxelenaren sailkapena 2. atalean egin dugun analisiarekin.

Bi azentu sistemek, Mitxelenaren Errenterikoak eta Berrondoren Oiartzungoak, lotura historiko zuzena duten heinean, printzipioz espero genuke Klase I-eko hitzak (bigarren silaban goranzko azentua dutenak) Mitxelenaren hitz normalen taldean egotea eta 
beste bi azentu klaseetakoak (azentua lehen silaban dutenak eta beheranzko azentua dutenak) bereziak izatea Mitxelenaren sailkapen bitarrean.

Hitzak bi zutabetan ipintzeaz gain, Mitxelenak azentu markak erabili zituen bere dokumentuan. Oro har, hitz normalek ez dute inolako markarik eta bereziek, aldiz, azentu grabea daramate azken bokalean, adib. premiyà, arrikà. Kasu gutti batzuetan, hala ere, hitzak normalen zutabean egon arren azentu marka du. Beharbada hitz horiek mugitu ziren lana inprentarako prestatzerakoan edo agian Mitxelenak iritzia aldatu zuen haien azentueraz. Bi zutabe eta azentu grabeaz gain, Echeniquek argitaratutako hitz zerrendan hitz askok ikur bat daramate aurrean: «+», «<», «>» eta zenbait kasutan «?». Ez dakit nola interpretatu behar diren ikur horiek eta ez ditut kontuan hartu. Ziur asko Mitxelenak marka horiek ipini zituen grabaketa eginda gero, beste honako ohar hau bezala: "Yo no distingo entre, por ej., eztittuzte biar: baittuzte 'ya los tienen', y eztittuzte biar, (baldin) baittuzte 'si los tienen'. Yo: sí.» Bide batez, esan behar da grabaketan Mitxelenak eta Berrondok euskaraz hitz egiten dutela denbora osoan. Beraz, ez dakit zergatik edo zertarako idatzi zuen Mitxelenak ohar hori erdaraz.

Zoritxarrez aztertu dudan grabaketan Mitxelenak erabili zuen zerrendaren hasierako hitz batzuk falta dira, haien artean oso esanguratsuak izango liratekeen bikote minimo batzuk. Aztertu dudan zatia utziya hitzarekin hasten da (ikus Echeniquek 1988 argitaratutako zerrenda).

Ikus dezagun, beraz, zein neurritan (1)ean egin dugun sailkapena bat datorren Mitxelenak egindako bereizkuntza bitarrarekin. Konparaketa horren emaitzak I. Taulan ipini ditut (ikus 16. irudia ere). Konparaketa horretarako aditz jokatuak eta pertsona izenak albora utzi ditut. Goian esan bezala, kasu batzuetan hitza «normalen» zutabean dago, baina Mitxelenak hitz bereziak adierazteko erabiltzen duen marka darama (azentu grabea azken bokalean). Hitz hauek ' $n x$ ' bezala sailkatu ditut. Alderantziz ere gertatzen da kasu gutti batzuetan: hitza berezien zutabean egon arren ez darama azentu markarik; hauek 'bx' taldean kontatu ditut.

1. Taula. Azentu klaseak eta Mitxelenaren sailkapena

\begin{tabular}{|l|c|c|c|c|} 
& Klase I & Klase II & Klase III & Guztira \\
\hline Normalak (n) & 276 & 21 & 14 & 311 \\
\hline Bereziak (b) & 54 & 29 & 239 & 322 \\
\hline Bereziak? (bx) & 3 & 1 & 3 & 7 \\
\hline Normalak? (nx) & 9 & 28 & 11 & 48 \\
\hline GUZTIRA & 342 & 79 & 267 & 688 \\
\hline
\end{tabular}

Argi dago neurri handi batean Mitxelenaren hitz normalak Klase I-ekoak direla eta bere hitz bereziak Klase III-an daudela, espero genuen bezala. Aipatzekoa da, halaber, 'nx' taldean jarri ditugun hitz gehienak («normalen» zutabean, baina berezien azentu ikurrarekin) Klase II-koak direla. 
Mitxelenaren sailkapeneko 311 hitz normal analizatu ditugu eta horietariko 276 Klase I-ean sartzen dira; hau da, lagin honetan Mitxelenaren hitz normaletariko \% 89k goranzko azentua daramate bigarren silaban Berrondoren ahoskeran gure analisian. Esan bezala, Mitxelenaren hitz bereziak, aldiz, batez ere Klase III-koak dira gure analisian; hau da erroaren lehen bi silabetan beheranzko tonua daramatenak: \% 74,2 (=239/322). Badirudi Mitxelenak zalantzak zituela 'nx' taldeko hitzen azentuaz (hau da, antza denez, zutabearen eta azentu markaren arteko desadostasuna ez da inprenta kontu hutsa). Horietariko gehienak ( $\% 58,3=28 / 48)$ Klase II-koak dira; hau da azentu "normala» dute (goranzkoa) baina silaba okerrean (lehen silaban).

Egin dugun analisi prosodikoa zuzena bada, honek guztiak esan nahi du Mitxelenaren intuizio prosodikoak (bere garaiko Errenteriko azentueran oinarrituta) eta Berrondoren Oiartzungo datuak ez direla hain desberdinak azentu klaseei dagokienez; are gehiago kontuan hartzen badugu Mitxelenaren Errenteriko sisteman bazirela bakarrik bi hitz mota, antza denez, eta Oiartzunen, aldiz, hitzak hiru (edo, ziur asko, lau) klase desberdinetan sailkatzen zirela azentueraren arabera, bai azentuaren kokagunea, baita doinua ere kontuan hartuz.

Hurrengo ataletan bereizi ditugun azentu klaseen banaketa lexikala kontsideratuko dugu sakonkiago. Taulan ikusten denez, lagin honetan Klase II-ko hitzek talderik ttikiena osatzen dute. Klase horrekin, beraz, hasiko gara hitzen prosodia miatzen, 4.1.atalean. Gero, 4.2. atalean Klase III-ko hitzak aztertuko ditugu. Klase I patroi prosodiko normala edo ez-markatua denez, beste hitz guztiak talde horretan sartzen dira. Kontuan hartu behar dugu lagin honen ehunekoak ez direla hiztegi osoaren isla, Mitxelenak kontrasteak aztertu nahi baitzituen.

Maileguak euskal jatorriko hitzetatik bereiziz, hurrengo ehunekoak aurkitzen ditugu: Klase I-ean \%40 maileguak dira gure laginean, Klase II-an \%57 eta Klase III-an \%49. Beraz, maileguak hiru azentu klaseetan aurkitzen baditugu ere, ugariagoak dira klase markatuetan, batez ere Klase II-an.

\subsection{Klase II-ko hitzak}

Esan bezala, Klase II-ko hitzek goranzko azentua daramate lehen silaban. Azentu klase honetan, alde batetik, erro silabakarreko hitzak ditugu:

(3) lúrrian, lúrretik, lúrrekua, lúrrezkua,

úrian, úretik, úrekua,

súrtatik, súrtakua,

gábekua, gábero,

zúrezkua, gáñekua, sóñekua, ítzikan, pózikan, góizero, ásteko ('hasteko'), áyena ('haiena'), láunaka

Neurri batean, erro silabakarreko hitzen azentueran Oiartzungo datu hauek bat datoz Goizuetako hizkerarekin (Hualde \& Lujanbio, 2008, 384. or.) eta Bortzirietakoarekin (Hualde 1997, 111-112. or.). Goizuetan erro silabakarreko izen-adjektiboek goranzko 
azentua hartzen dute erroan singularrean eta beheranzkoa pluralean. Gure grabaketan ez dut pluralik aurkitu mota honetako hitzekin. Horretaz gain, Goizuetan eratorpen atzizki batzuek ere beheranzko azentua eragiten dute: gàbero, gòizero ${ }^{3}$. (3)n erakutsi bezala, gure datuetan ez dugu hori aurkitu. Badirudi, dena den, beste eratorpen atzizki batzuek beheranzko azentua eragiten dutela Berrondoren hizkeran, adib. lìrpekua, -pe atzizkiarekin.

Bigarrenik, erro bisilabaduneko mailegu batzuk ditugu Klase II-an, gehienak zaharrak edo ez oso berriak, jatorriko hizkuntzan azentua lehen silaban dutenak, Goizuetan bezala kasu honetan ere ${ }^{4}$. Hona hemen laginean aurkitu ditugunak:

(4) ánkakua, báñua, dénda, dírua, díruduna, fésta bat, géla bat, kájakua, kálekua, káñua, kália, káliza, káskua, kójua, kórdia, kórrika, kóstakua, kóstia, mártxua, méza bat, múnduan, múndukua, mútutua, pála bat, párekua, párian, pázkua, písua, pórrua, pútzura, sédazkua, sókakin, sóñua, trípakua

Talde horretan letren izenak ere sartzen dira. Mitxelenak bi bikote minimo erabiltzen ditu letra izenekin: $M$ bat [éme] vs emé bat eta $R$ bat [érre] vs. erré bat. Badira, baita ere, toponimo batzuk, hala nola Lézokua, Bérakua eta Prántziyan.

Azkenik, zenbait euskal jatorriko hitz arrunt ere kausitzen ditugu azentu patroi honekin:

(5) áita, sémia, néska bat,

éra bat,

jántziya, jósita,

ijuka, míatxua ('bigantxa'),

bázkaiya, éndanan ('ilaran'), ólako, kóntzeko

Euskal jatorriko bisilabadunak eta luzeagoak oso guti dira Klase II-n. Ohar batzuk egin behar dira beraz (5)eko hitzei buruz. Hasteko, áita eta sémia hitzen azentuera bat dator Goizuetakoarekin. Aldiz, néska hitza ez da sartzen klase honetan Goizuetan.

Goizuetan /j/-z hasten diren aditz guztiek lehen silaban daramate azentua (Hualde $\&$ Lujanbio, 2008, 389. or.). Oiartzunen aditz horiek frikari belarraz hasten dira, baina laginean ditugun biak, jántziya eta jósita, ados daude Goizuetako azentuerarekin.

Luzeagoetan, bázkaiya hitza bazkària da Goizuetan, beheranzko azentuarekin bigarren silaban. Kasu honetan, kontrazio etimologikoak esplikatzen du azentuera berezia, h.d. barázkari > bázkari bazkàri. Taldean beste hirusilabadun dugu, éndanan. Gure grabaketan hiztunak behin horrela esaten badu ere, beste batean endàna esaten du.

3 Bestalde, Goiz. astèko 'hasteko' dugu.

4 Adostasuna ez da osoa, adib. Goiz. dirúduna, kàjakoa. Hau da, adostasuna dugu joera orokorrean, baina ez adibide guztietan. 
Beharbada erro hirusilabaduneko hitz batzuekin azentuera aldakorra zen bi aukera markatu horien artean. Esan behar da Klase III-ko hitz luzeak batzuetan hasten direla tonu erlatiboki altuaz, bigarren silaban beheratzen dena. Tonu kontornu honek zalantzak eragin ditzake hitzaren azentueraz; hau da, jakiteko hitzak $\mathrm{H}$ tonu bat duen lehen silaban ala L tonu bat bigarren silaban: ijìtua, imàjiña, ixtòriya. Kasu horietan intentsitatea eta iraupena erabili ditugu azentuaren kokagunea erabakitzeko, ikus 8 . eta 10. irudiak.

\subsection{Klase III-ko hitzak}

Klase III-ko hitzetan azentua beheranzkoa da. Esan bezala, kasu batzuetan silaba azentuduna lehendabizikoa da eta beste batzuetan bigarrena. Hala ere, grabaketan ez dago beti guztiz argi beheranzko tonua zein silabatan kokatzen den. Arrazoi horregatik, bi azentu motak (hau da, Hualde \& Lujanbioren (2008) Klase III eta Klase IV) ez ditugu bereizi hemen.

Azentu bereizgarria duten mendebaldeko eta erdialdeko hizkeretan, azentu markatua edo berezia duten hitzak antzekoak dira neurri handi batean (Gaminde \& Hualde, 1995). Adibidez, beste hizkera askotan bezala, hurrengoek azentuera markatua dute gure grabaketan: àtzekua, àurrekua, belàrriya, lengùsua, ollàxkua. Funtsean, talde prosodiko honetako hitzak maileguak, hitz eratorriak eta konposatuak dira. Gure datuetan Klase III-ko hitz gehienak mota horietakoak dira. Antza denez eratorpen atzizki batzuek beheranko azentua eragiten dute sistematikoki, (6)ean erakusten den moduan (baina ikus (3)):

(6) Klase III-ko hitz eratorriak

/-(t)arr/ irùndarra, gùtarra, pasàitarra, lèzoarra

/-ti/ bildùrtiya, màstiya

/-ki/ tripàkiya, odòlkiya, xaxpìkiya, egòkiya

/-txu/ astòtxua, àurtxua

/-en/ edèrrena, jatòrrena, laugàrrena, gòrrena

/-zko/ pànazkua

/-pe/ ànkapian, àrkupia, ùrpekua, ùrpian

/-te(g)i/ aràteya, aròzteiya

/-dun/ èrdalduna, èuskalduna

/-era/èuskeraz, èrderaz, gàldera, juàyera, etòrrera, ìzkera

/-ero/ arràtsero, ùrtero

/-ka/ arrika, astòka, bànaka, biñaka, òyuka, usàika, zìrika

/-zai/ àurtzaya

Hitz elkartuen artean, galbàya, illàbete eta suàrriya aurkitzen ditugu.

Toponimoak edozein klasetakoak izan daitezke gure laginean, adib Oyártzun, Donóstiyan, Erníyon, Azkóitiyan, Endáyan (K-I), Lézokua (K-II), Goizùtan, Orìon, Pasàyan (K-III). Badirudi, bestalde, herri izenek beheranzko azentua hartzen dutela ezizen bezala erabiltzen direnean, adib Tolósa, herria, baina Ttolòxa ezizena. 
Ezizenen toponimikoen azentuazio berezia fenomeno ezaguna da Gipuzkoako eta Bizkaiko beste hizkera askotan eta argi dago hori zela Mitxelenaren intuizioa ere (Goizuetan ere horrela da).

Maileguei dagokienez, Goizuetan egokitzapen arau interesgarri bat aurkitzen dugu. Alegia, azentua lehen edo bigarren silaban duten mailegu silababakar eta bisilabidun gehienek beheranzko azentuarekin egokitzen dira (Hualde, 2008). Badirudi egokitzapen arau hori erabiltzen zela Oiartzunen ere. Gure grabaketan hiztunak esplizitoki aplikatzen du kasu batean. Euskaraz [ankìná] ahoskatu ondoren, Berrondok honako galdera egiten dio Mitxelenari: "[anxína] edo zer da hau?». Hau da, gazt. angina [anxína] $\rightarrow$ eusk. [ankìná]. Beste batzuen artean, (7)eko maileguak aurkitzen ditugu grabaketan. Gehienak hirusilabadunak dira, batzuek zaharrak eta beste batzuek berriagoak:

(7) Klase III-ko maileguak

a. Erro bisilabadunak: abìlla, apàiza, bàixua, bàla bat, gàuza bat, fuèrtia

b. Hiru silabako mailegu zaharrak: aingìra, aizkòra, alkàtia, ànima, àntzara, dènbora, gànbara, ixpìllua, ijitua, eskòla, katìllua, kayòla, medikua, prèmiya

c. Hiru silabako mailegu berriagoak: angùla, àntsiya, bonbilla, gorbàta, kanpàna, kamilla, kuñàdua, pelòta, relòjua, tronpèta, txalùpa

Esan bezala egokitzapen arau emankorra da hau. Batzuetan mailegu zahar bat Klase I-ekoa da jatorriko hizkuntzan azentua bigarren silaban badu eta, aldiz, oso antzekoa den beste mailegu berriago bat Klase III-koa da, adib. koñáta vs koñàdua.

\section{LABURBILDUZ}

Aztertu dugun grabaketak Oiartzungo hizkeraren azentuera zaharraren berri ematen digu. Azentua den bezainbatean, hitzek lehen edo bigarren silaban izan dezakete azentua eta azentu hori goranzkoa edo beheranzkoa izan daiteke. Gainera, hitz solteetan (edo galdegaian) beste tonu gailur bat dugu azken edo azkenaurreko silaban. Guzti honetan sistema honek antza handia du gaurko Goizuetakoarekin.

Grabaketa egin baino lehen, Mitxelenak aztertu zituen hitzak bi taldetan banatu zituen: hitz normalak eta hitz bereziak. Gure azterketa bat dator, neurri handi batean, Mitxelenaren banaketarekin. Hitz normal gehienek goranzko azentua dute bigarren silaban eta Mitxelenaren berezi gehienek beheranzko azentua dute.

Oiartzungo azentuera zaharra eta Goizuetakoa oso antzekoak badira ere, isoglosa prosodiko garrantzitsu bat iragaten da bi herrien artetik. Goizuetako euskaran, Nafarroako beste hizkera askotan bezala, bokalak asko luzatzen dira silaba azentudunetan eta murrizten azentugabeetan. Horrek bokal erorketa gertakariak eragiten ditu silaba azentugabeetan (aferesia, adib. esan > san eta sinkopa, adib. pasatu > pastu). Oiartzunen, aldiz, ez dugu aurkitzen iraupenaren indartze hori azentu ezaugarri bezala eta sinkopa eta aferesi fenomenoak ez dira nabariak. 


\section{IRUDIAK}

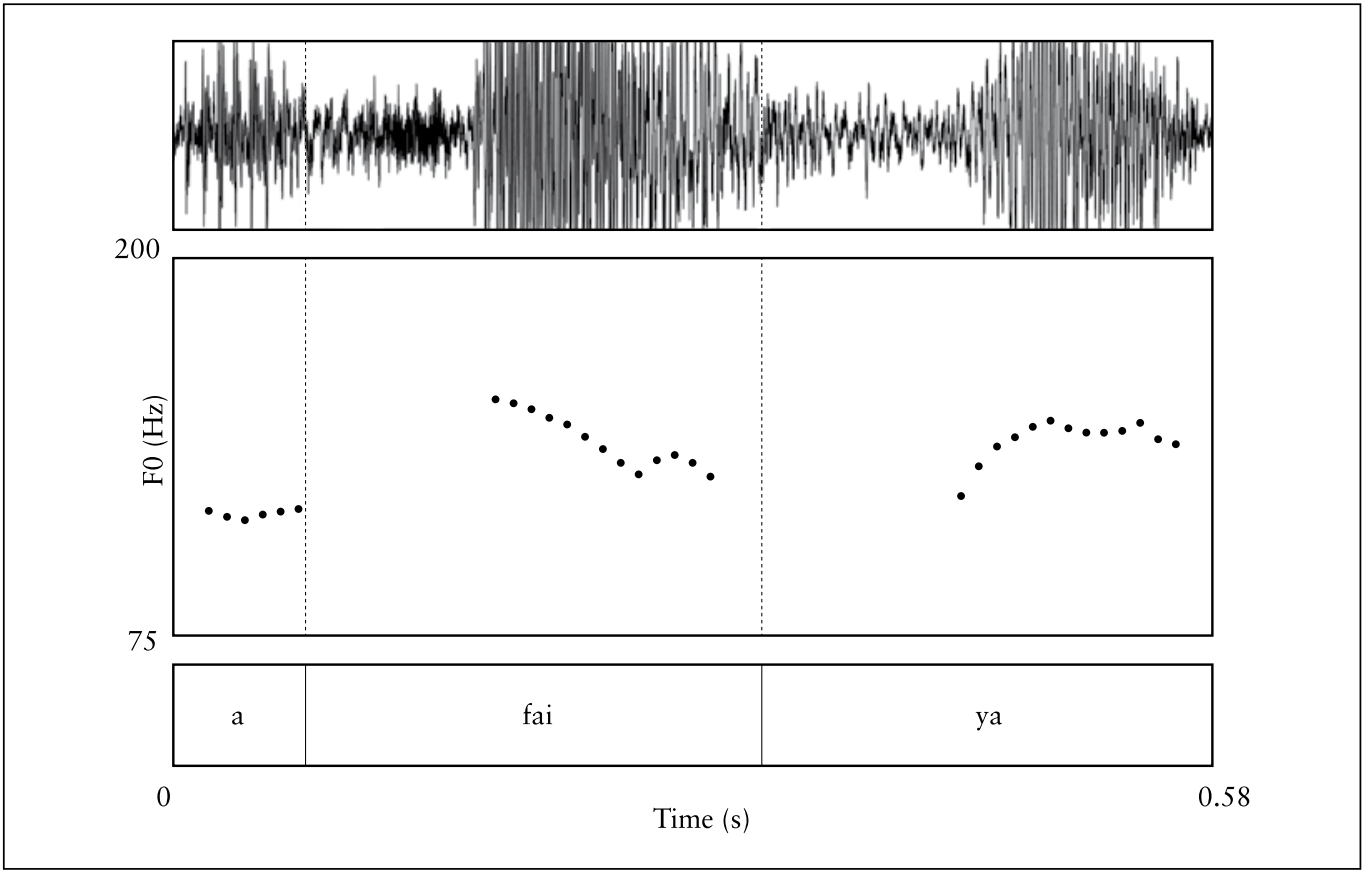

1. irudia. [afáiyá]. Klase I: Goranzko azentua bigarren silaban.

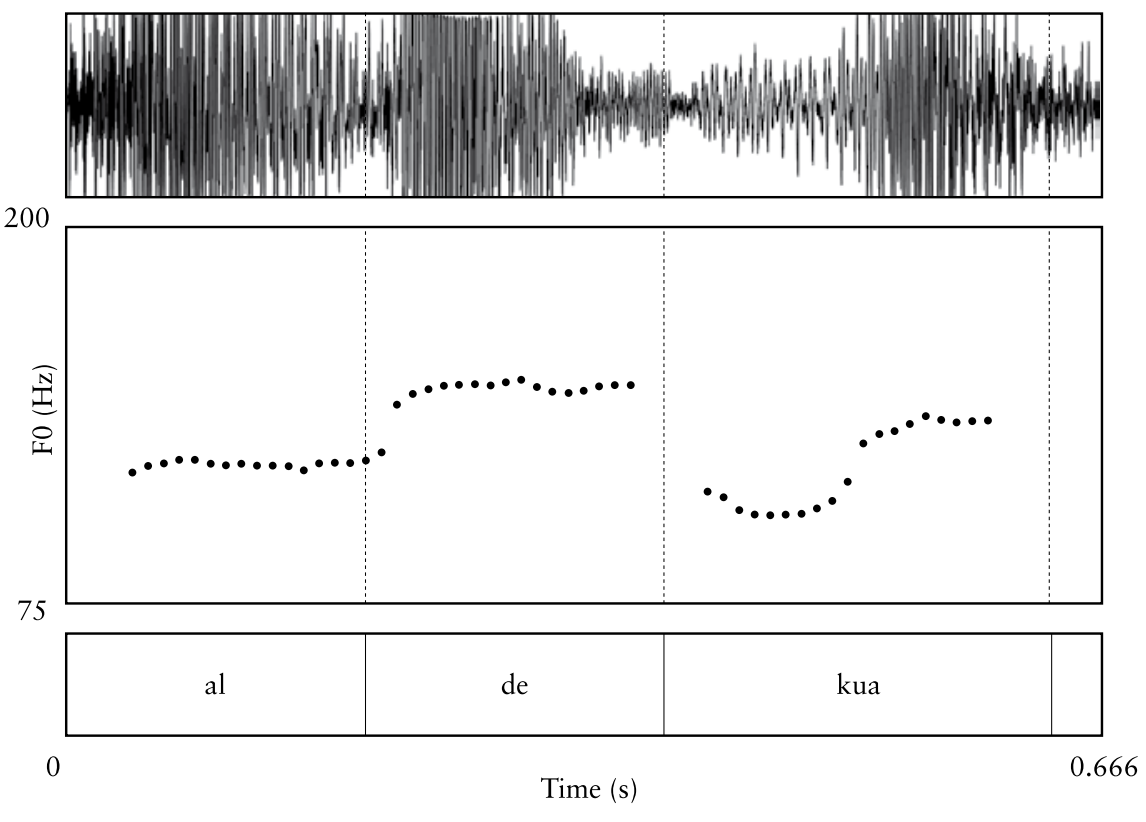

2. irudia. [aldékuá] Klase I: Goranzko azentua bigarren silaban.

124 Fontes Linguae Vasconum (FLV), 125, enero-junio, 2018, 113-132

ISSN: 0046-435X ISSN-e: 2530-5832 


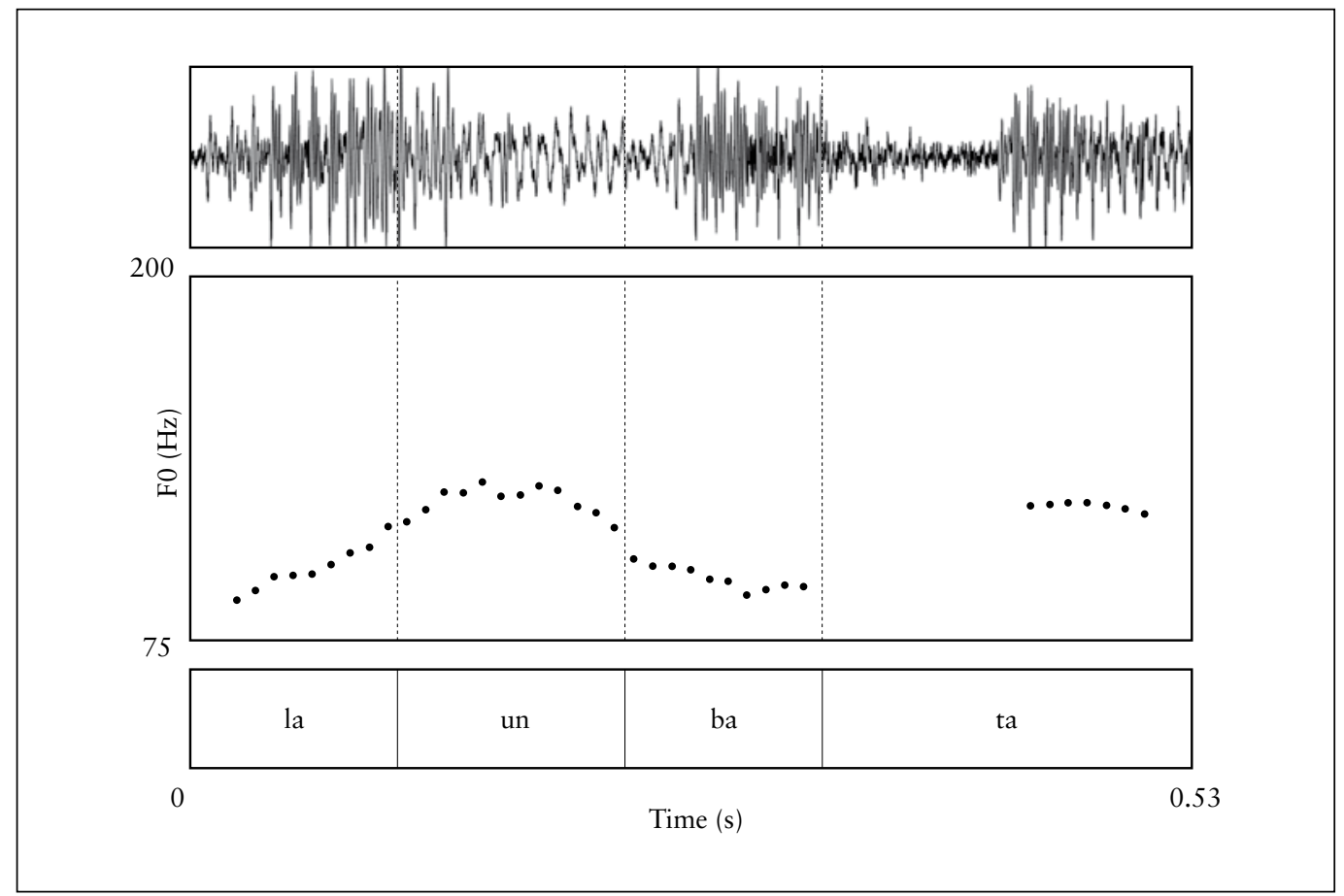

3. irudia. [la.únbatá] Klase I: Goranzko azentua bigarren silaban.

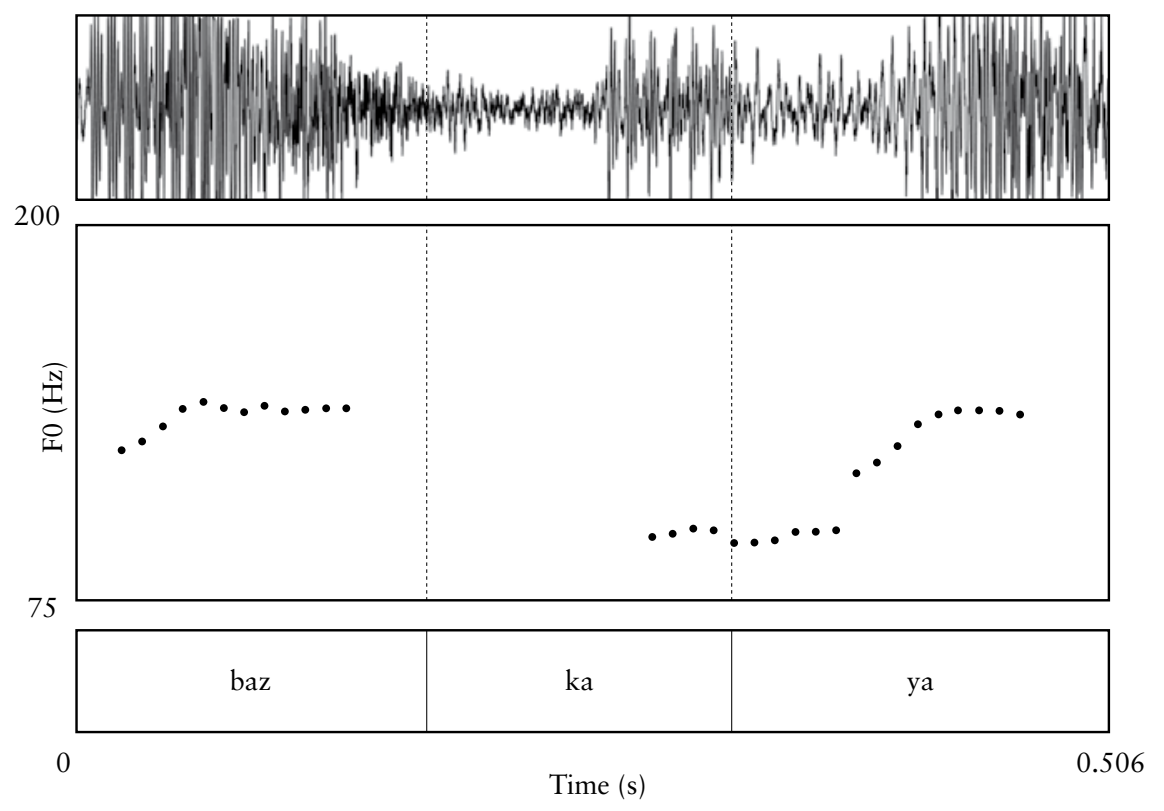

4. irudia. [bázkayá] Klase II: Goranzko azentua lehen silaban. 


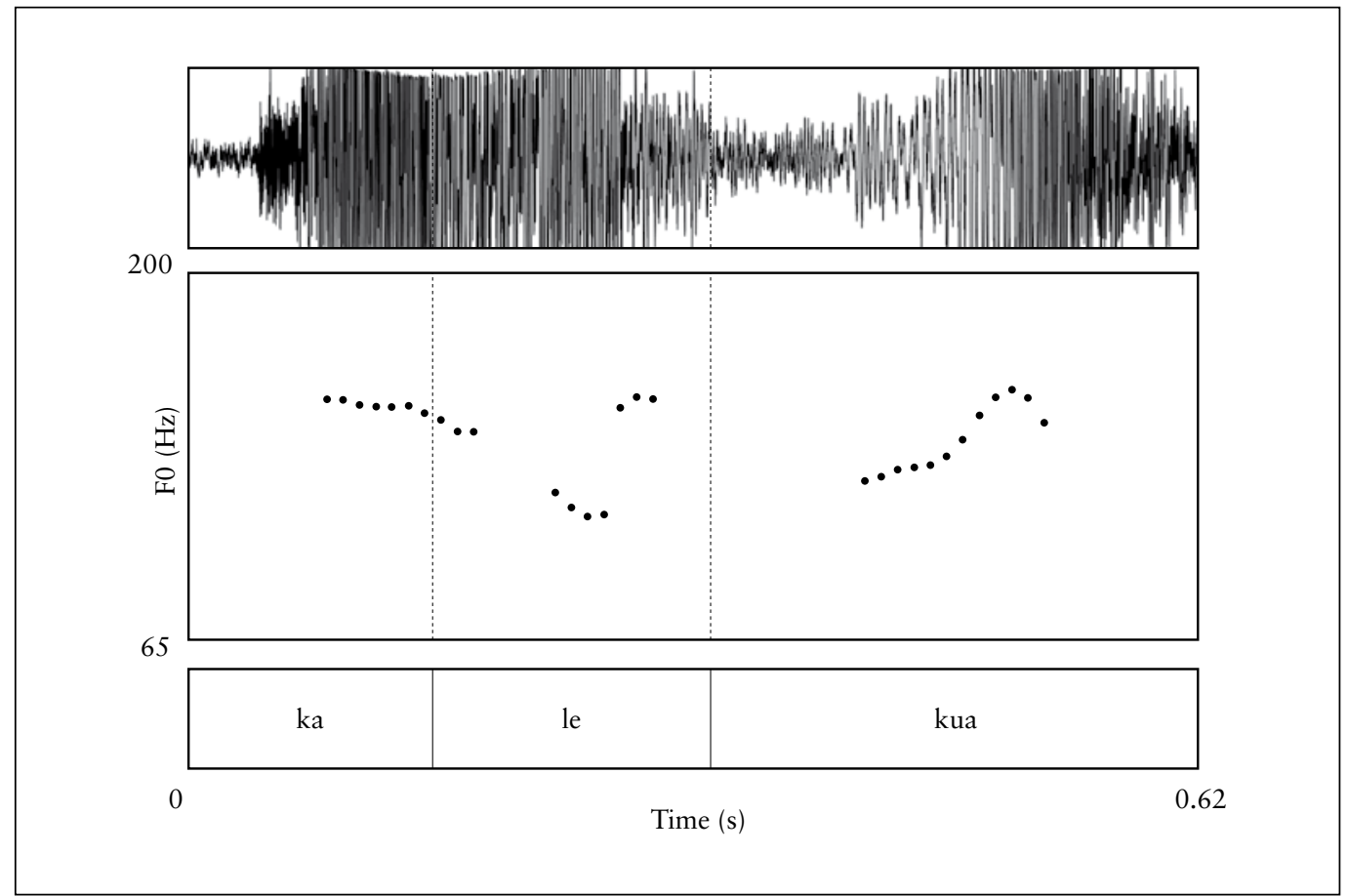

5. irudia. [kálekuá] Klase II: Goranzko azentua lehen silaban. (Bigarren silabaren bukaeran F0-bilatzaile automatikoak hiru errore egin ditu).

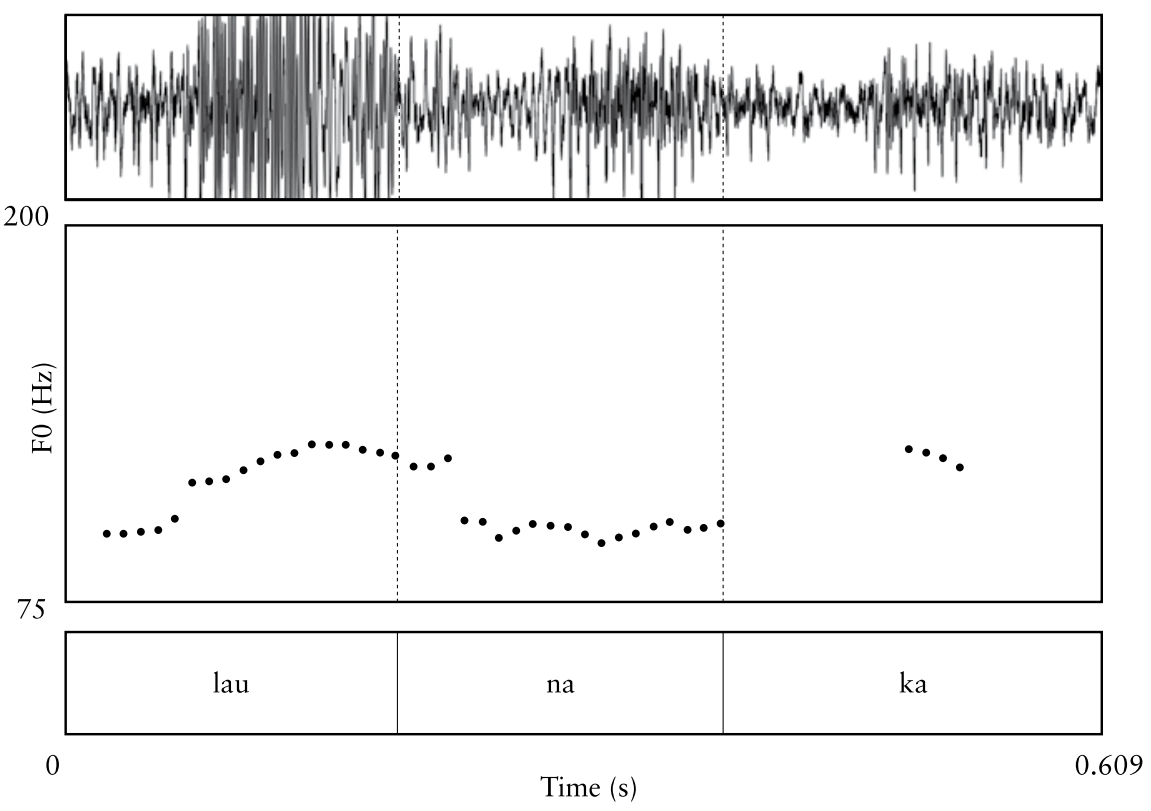

6. irudia. [láunaká] Klase II: Goranzko azentua lehen silaban.

126 Fontes Linguae Vasconum (FLV), 125, enero-junio, 2018, 113-132

ISSN: 0046-435X ISSN-e: 2530-5832 


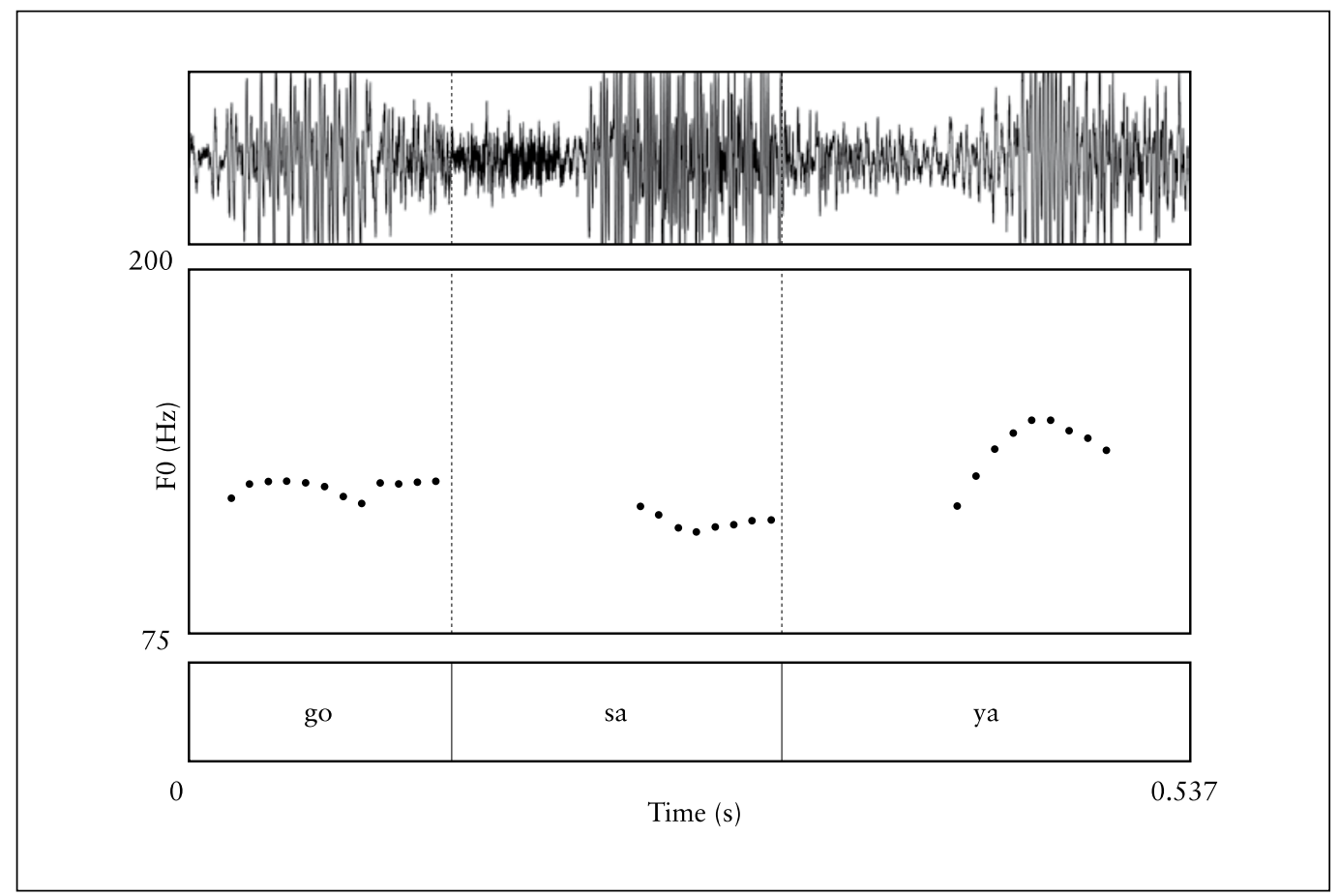

7. irudia. [gosàiyá]. Klase III: Beheranzko azentua bigarren silaban.

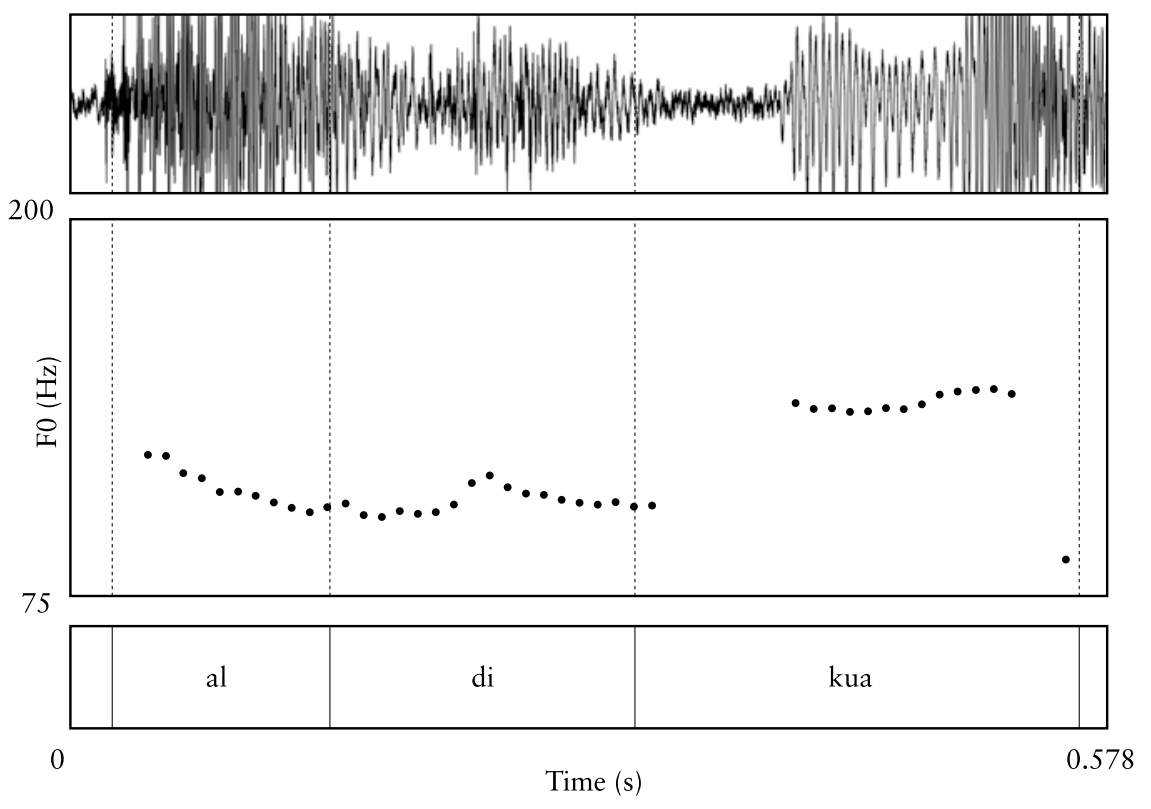

8. irudia. [aldikúa]. Klase III: Beheranzko azentua bigarren silaban. 


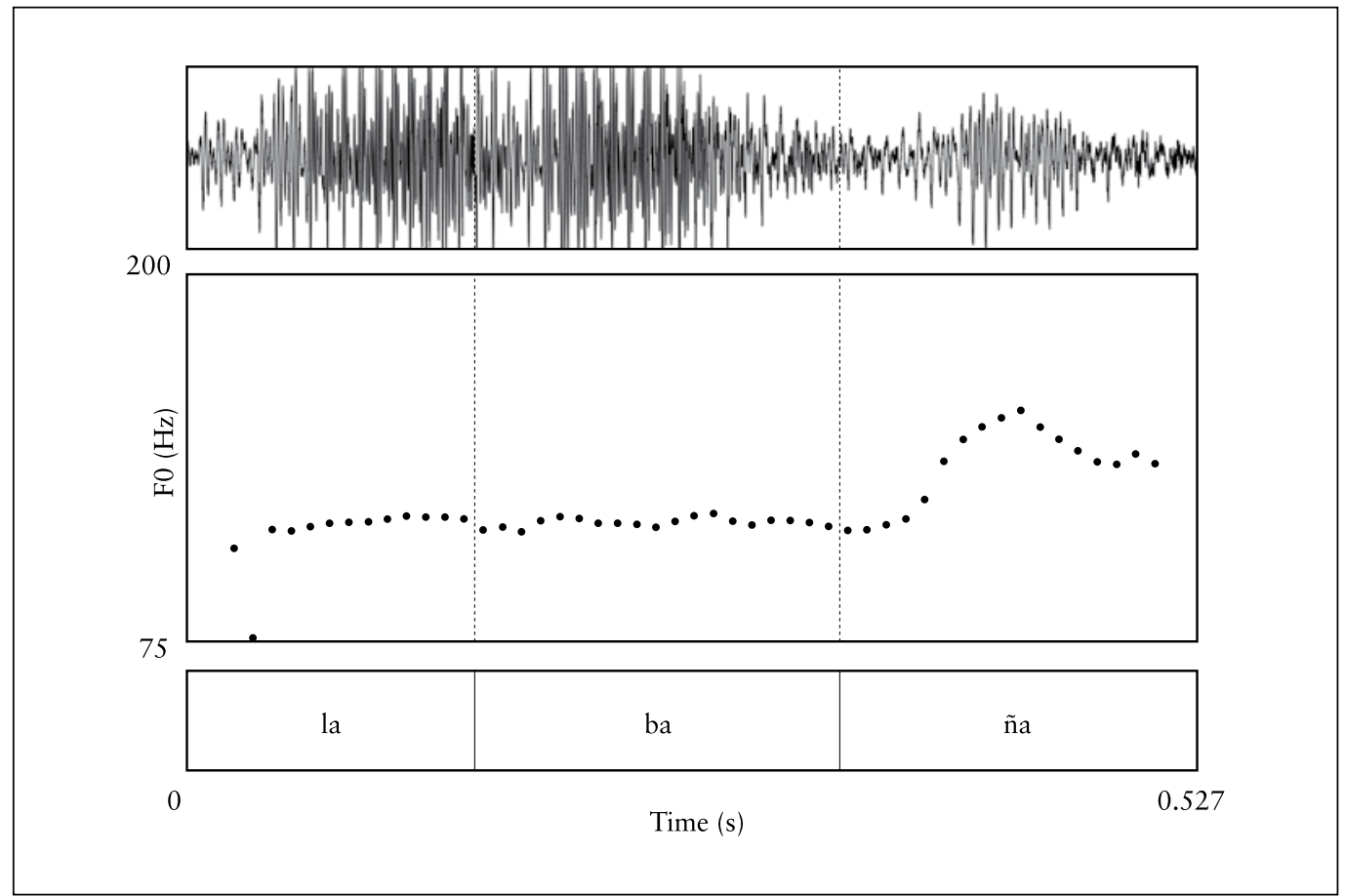

9. irudia. [labàñá]. Klase III: Beheranzko azentua bigarren silaban.

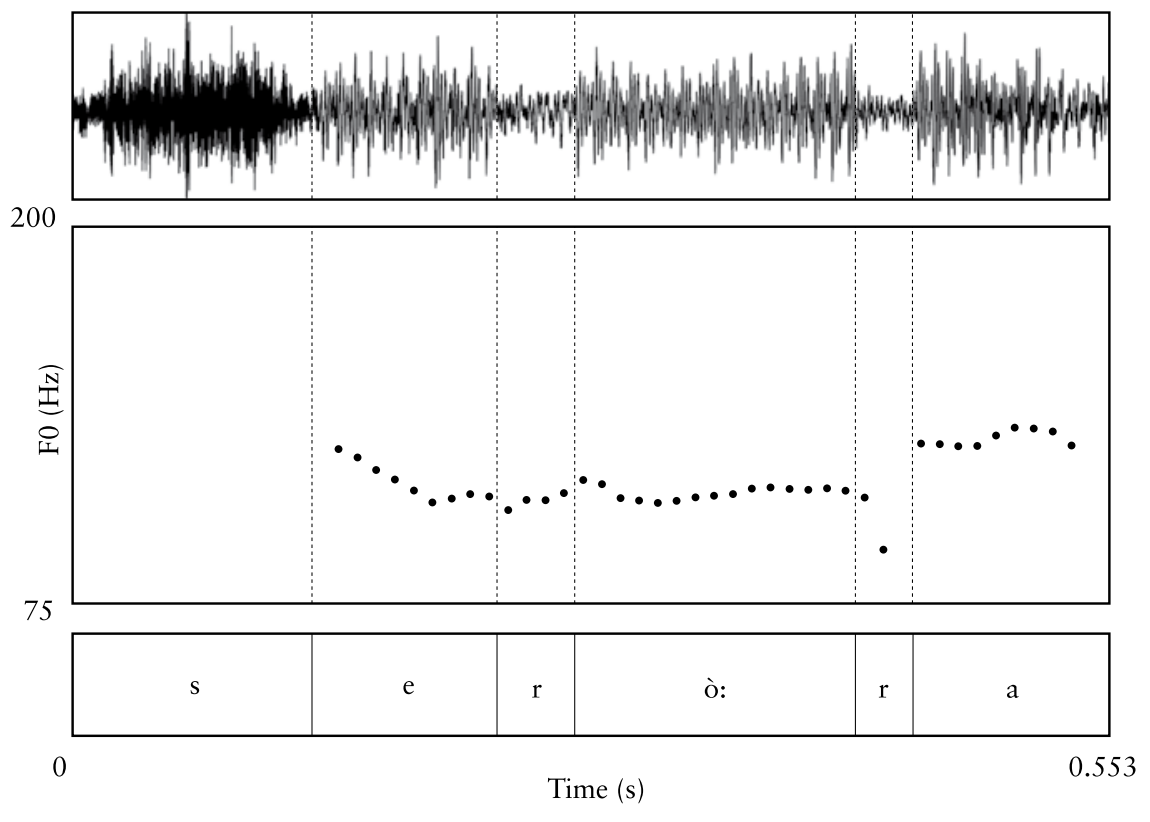

10. irudia. [seròrá]. Klase III. Beheranzko azentua bigarren silaban.

128 Fontes Linguae Vasconum (FLV), 125, enero-junio, 2018, 113-132

ISSN: 0046-435X ISSN-e: 2530-5832 


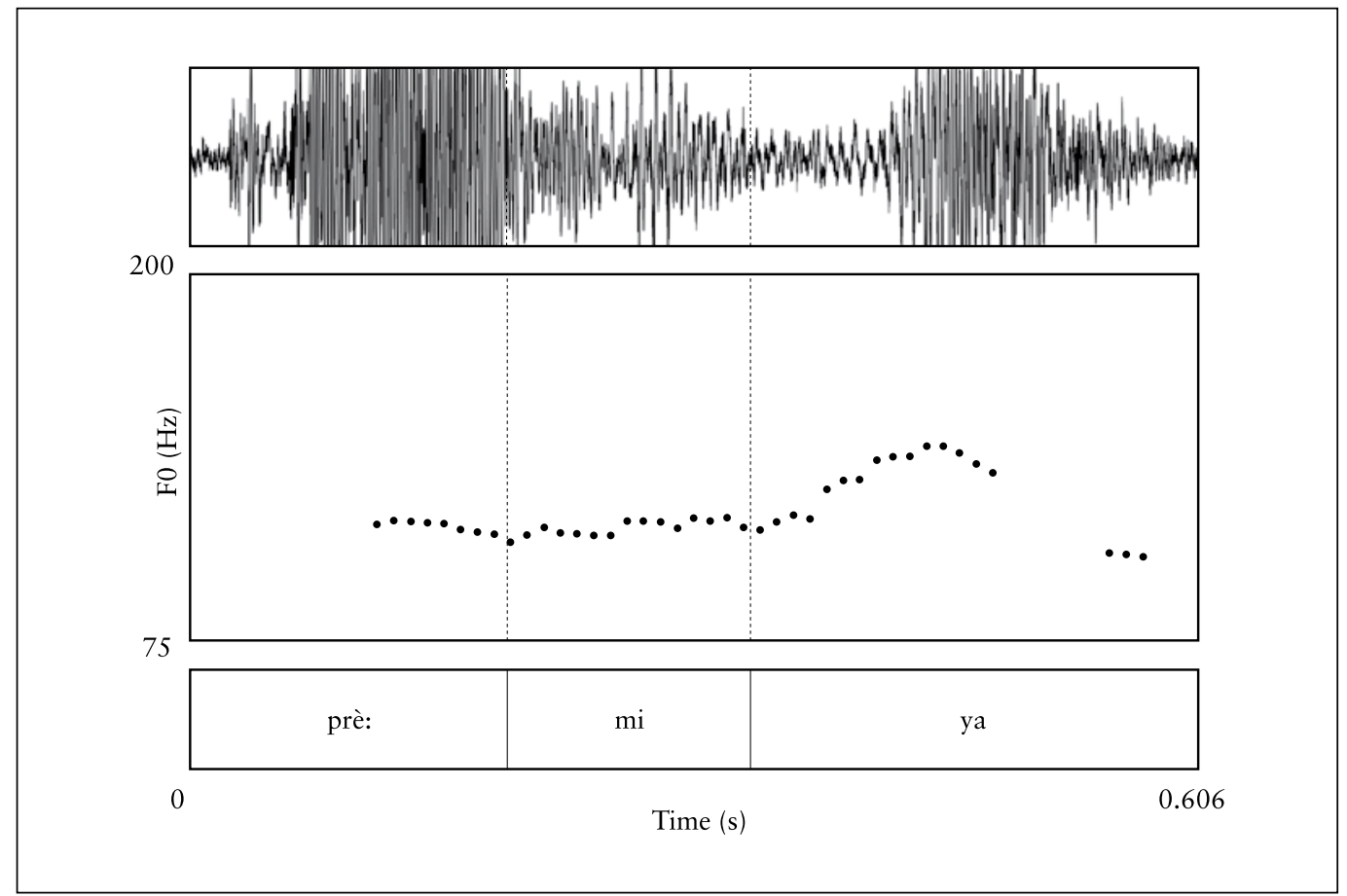

11. irudia. [prèmiyá]. Klase III: Beheranzko azentua lehen silaban. Adibide honetan lehen silaba bigarrena baino askoz intentsuagoa da (ikus uhinaren zabalera).

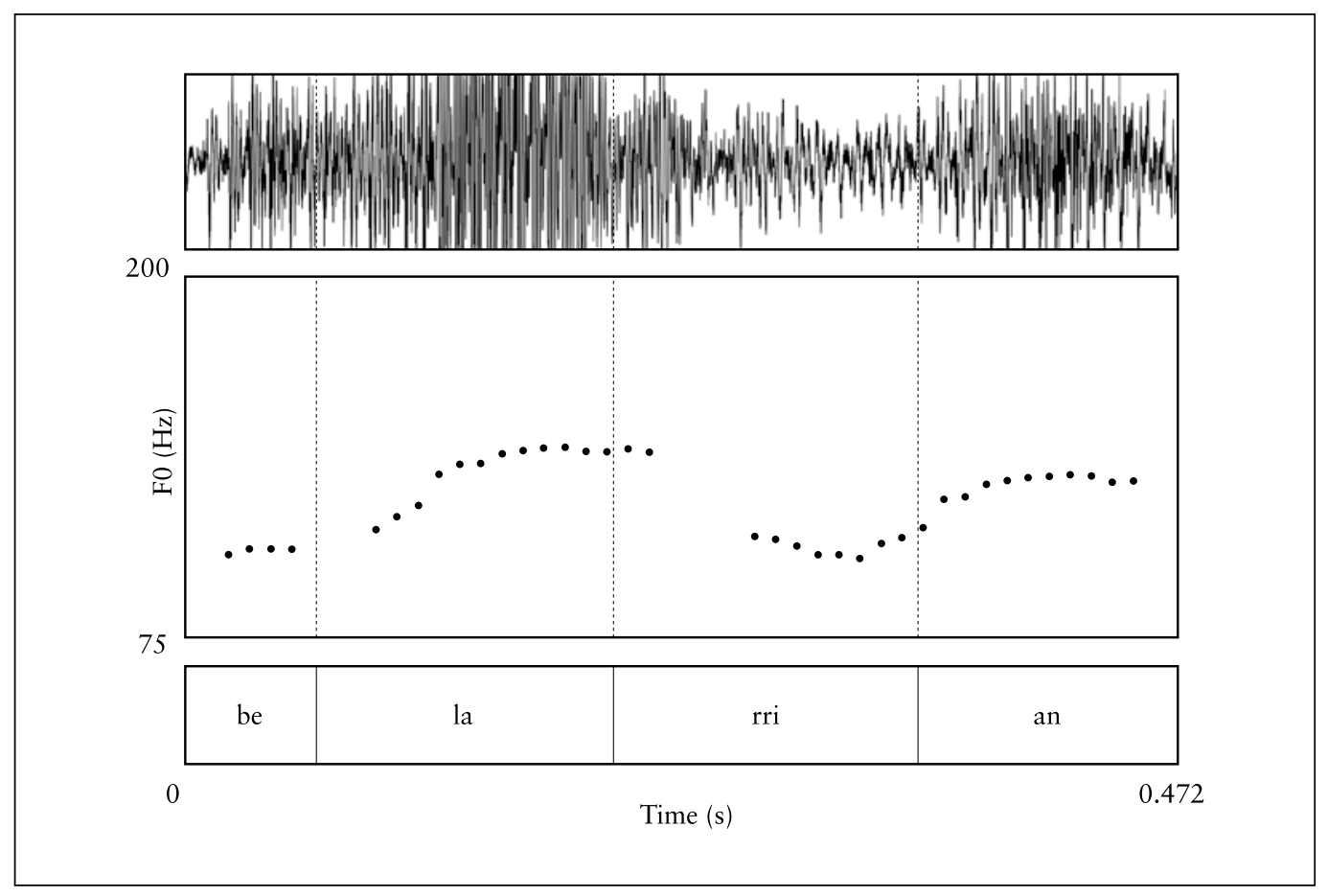

12. irudia. [belárrián] 'belarrean’. Klase I: Goranzko azentua bigarren silaban. 


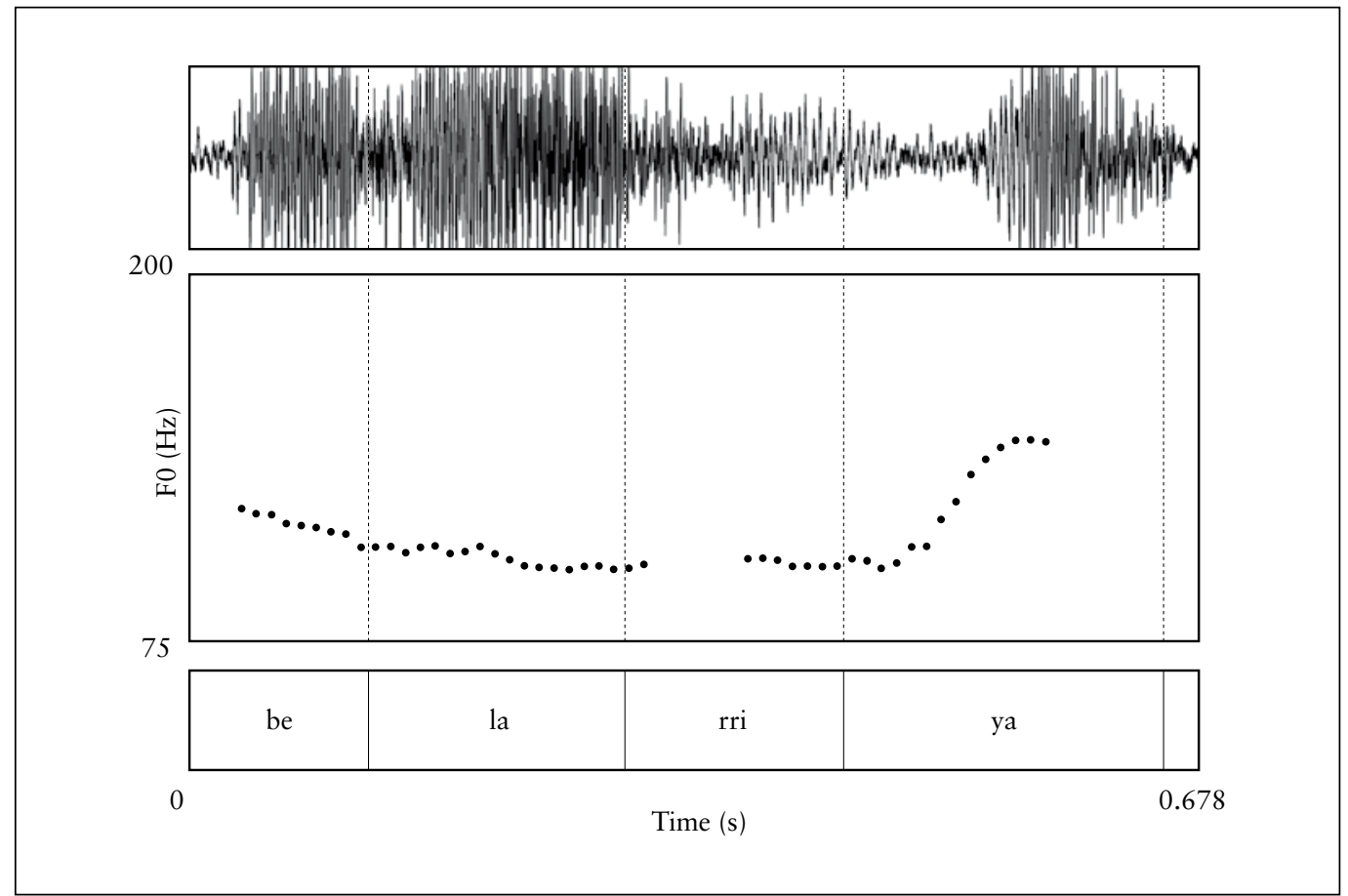

13. irudia. [belàrriyá] 'belarria'. Klase III: Beheranzko azentua bigarren silaban.

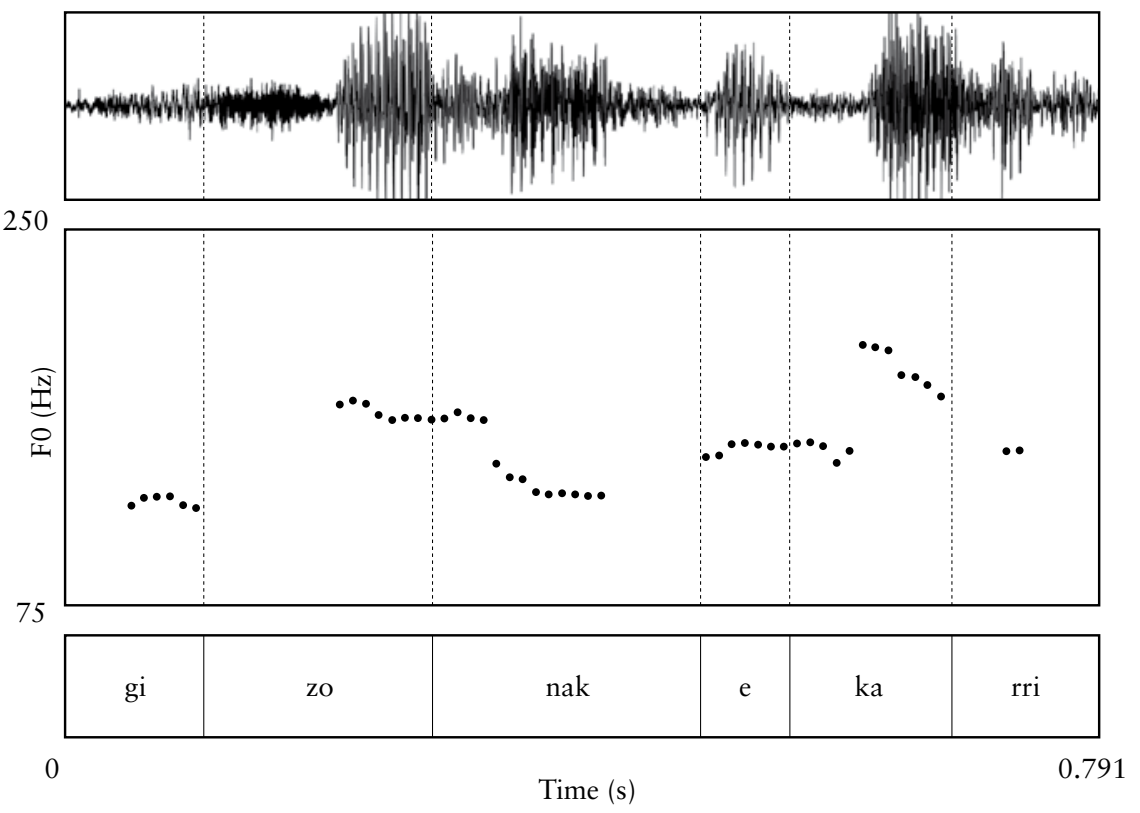

14. irudia. Gizónak (erg sg) ekárri (ttu) 'el hombre los ha traído’.

130 Fontes Linguae Vasconum (FLV), 125, enero-junio, 2018, 113-132 ISSN: 0046-435X ISSN-e: 2530-5832 


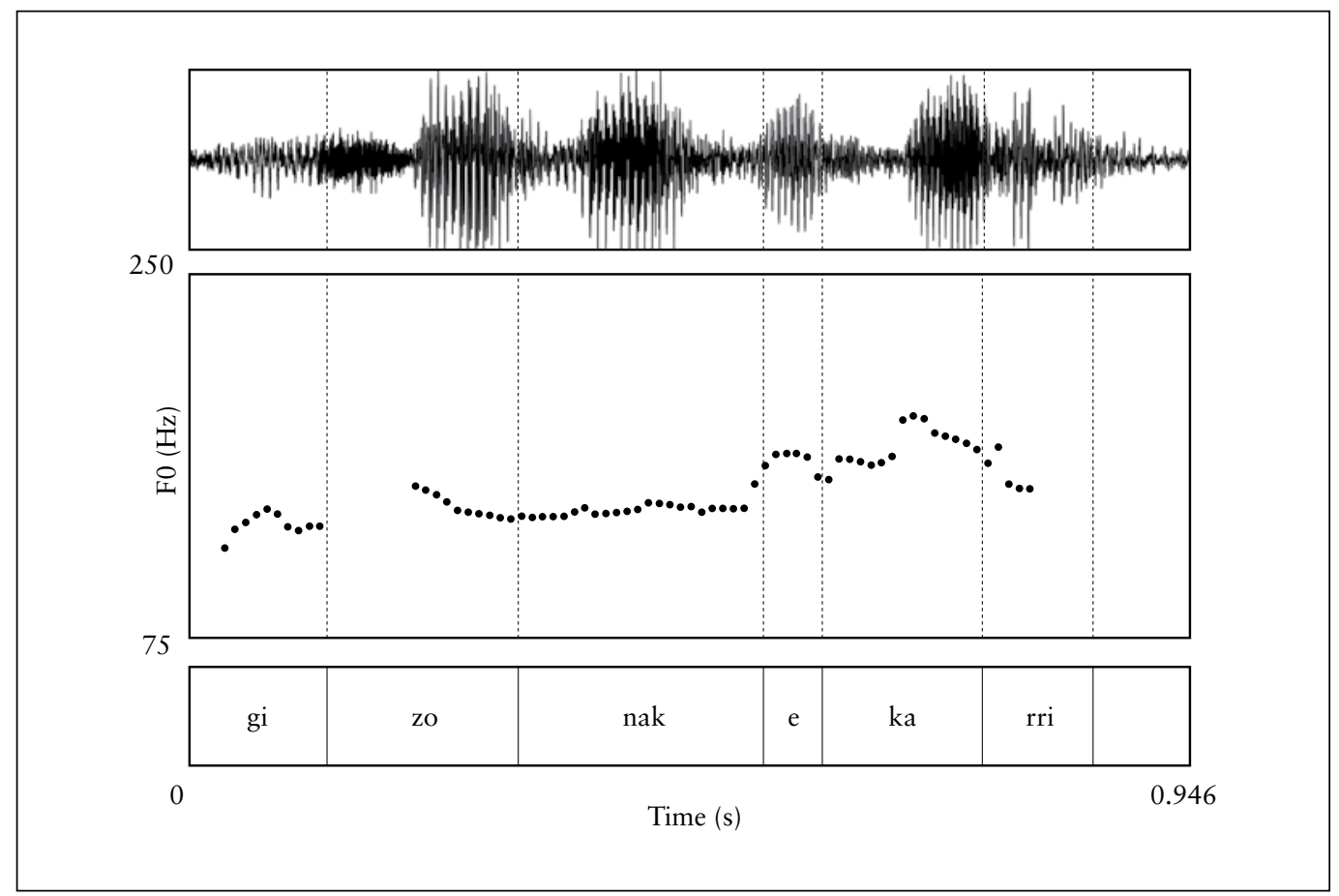

15. irudia. Gizònak (abs pl) ekárri (ttu) 'ha traído a los hombres'.

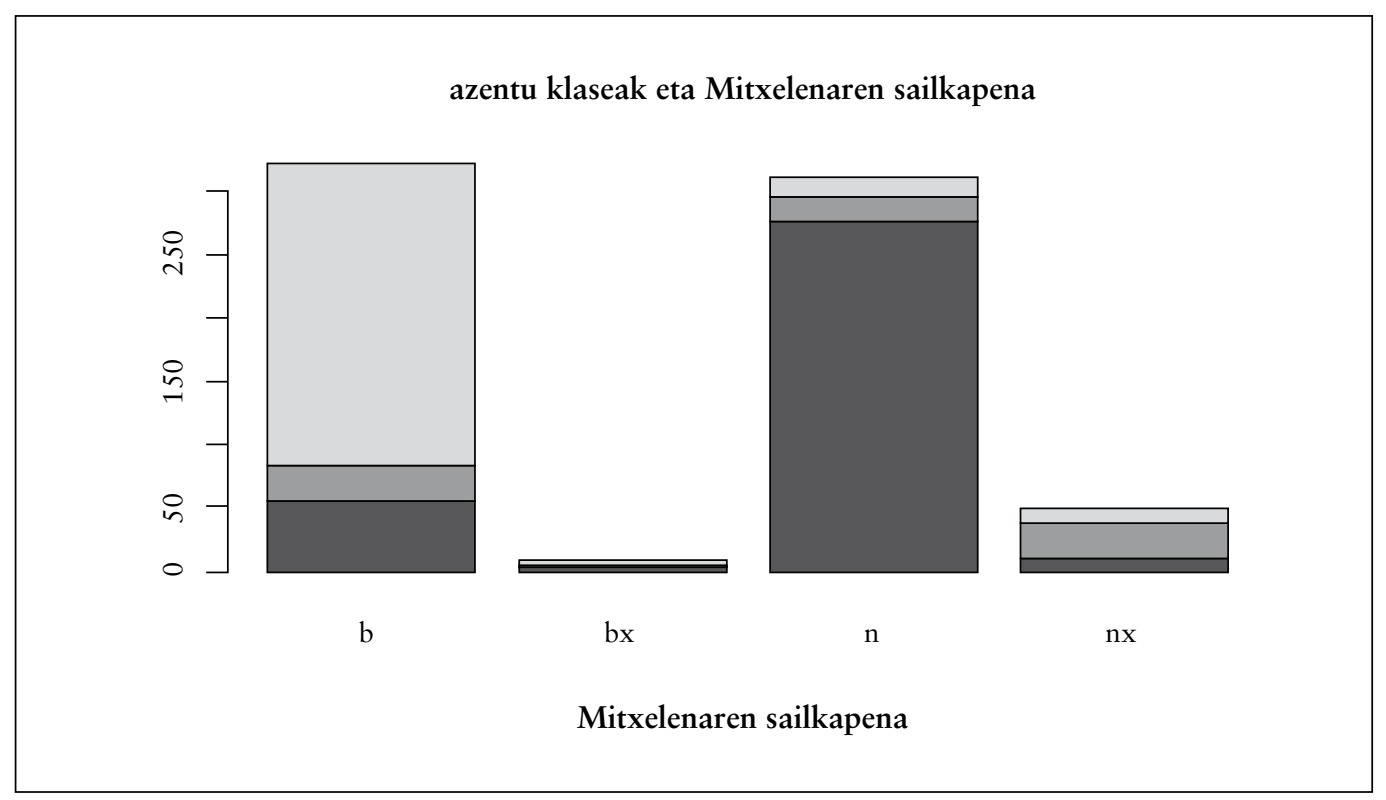

16. irudia. Mitxelenaren sailkapena eta gure analisia: beltza = Klase I, gris iluna = Klase II, gris argia = Klase III. 


\section{ERREFERENTZIAK}

Boersma, P. \& Weenink, D. (2017). Praat: doing phonetics by computer, version 6.0.30 [computer program]. www.praat.org.

Echenique, M. T. (1988). Stress and pitch (Luis Mitxelena zenak utzitako langaia). Euskera, 33, 495-521.

Gaminde, I. \& Hualde, J. I. (1995). Euskal azentuen atlaserako: zenbait isoglosa. ASJU, 29, 175-198.

Hualde, J. I. (1997). Euskararen azentuerak. Donostia \& Bilbo: Gipuzkoako Foru Aldundia \& UPV/EHU. (ASJUren gehigarriak XLII).

Hualde, J. I. (2008). Acentuación y cronología relativa en la lengua vasca. Oihenart, 23, 199-217.

Hualde, J. I. \& Lujanbio, O. (2008). Goizuetako azentua. In X. Artiagoitia \& J. Lakarra (arg.), Gramatika jaietan: Patxi Goenagaren omenez (377-394. or.). Bilbo: UPV/EHU.

Hualde, J. I., Lujanbio, O. \& Torreira, F. (2008). Lexical tone and stress in Goizueta Basque. Journal of the International Phonetic Association, 38(1), 1-24.

Irurtzun, A. (2006). Fonetikak bideratutako aldaketa fonologikoak. Oihenart, 21, 195-208.

Jacobsen, W. (1972). Nominative-ergative synchretism in Basque. ASJU, 6, 67-109.

Mitxelena, L. (2011 [1977]). Fonética histórica vasca. (Berrarg. in Obras completas VI, J. Lakarra \& I. Ruiz Arzallus (arg.), ASJUren gehigarriak LVIII).

132 Fontes Linguae Vasconum (FLV), 125, enero-junio, 2018, 113-132

ISSN: 0046-435X ISSN-e: 2530-5832 